\title{
Polish adaptation of the lowa Satisfaction with Anaesthesia Scale
}

\author{
Polska adaptacja lowa Satisfaction with Anesthesia Scale
}

\author{
Danuta Dyk', Dorota 0zga ${ }^{2}$, Aleksandra Gutysz-Wojnicka³, \\ Bogumił Lewandowski ${ }^{2}$, Marek Wojtaszek²
}

\begin{abstract}
1 Zakład Pielęgniarstwa Anestezjologicznego i Intensywnej Opieki, Uniwersytet Medyczny w Poznaniu/ Department of Anaesthesiological and Intensive Care Nursing, Medical University of Poznan

2 Katedra Ratownictwa Medycznego, Uniwersytet Rzeszowski/

Department of Emergency Medicine, Faculty of Medicine, University of Rzeszow, Poland

${ }^{3}$ Katedra Pielegniarstwa, Wydział Nauk Medycznych, Uniwersytet Warmińsko-Mazurski w Olsztynie/ Department of Nursing, University of Warmia and Mazury, Olsztyn, Poland
\end{abstract}

CORRESPONDING AUTHOR/AUTOR DO KORESPONDENCJ:

Dorota 0zga

Katedra Ratownictwa Medycznego, Uniwersytet Rzeszowski

ul. Pigonia 6; 35-959 Rzeszów

tel. +48178721195

e-mail: gdozga@poczta.fm

ABSTRACT

Key words:

STRESZCZENIE

Słowa kluczowe:
POLISH ADAPTATION OF THE IOWA SATISFACIION WITH ANAESTHESIA SCALE

Introduction. The paper presents the adaptation of the lowa Satisfaction with Anesthesia Scale to the conditions in Polish hospitals. Methods. The proces of cultural adaptation of the lowa Satisfaction with Anesthesia Scale was divided into three stages. The first stage was to formulate the Polish version of the ISAS. Secondly, the scale was used in the group of patients who were diagnosed with a maxillofacial injury and underwent surgical procedure. The final stage evaluated the psychometric features of the Polish version of the ISAS.

Results. 195 questionnaires were completed correctly and they were subject to further analysis. The questionnaires were collected from patients residing at the Maxillofacial Surgery Clinical Ward who were operated under a general anaesthesia due to a maxillofacial trauma. The average result of the satisfaction with anaesthesia in a studied group was 0.77 (scale from -3 to +3 ) $M=2, S D=2.41$. The Cronbach's alpha coefficient calculated for 11 multiple choice questions was 0.598 . It would be possible to increase the Cronbach's aplha coefficient if question no. 1 (I vomited or felt nauseous) was eliminated from the test (maximum 0.601). Every item on the scale had significant influence on the general result $(\mathrm{p}=0.0001)$.

Conclusions. Polish version of the lowa Satisfaction with Anesthesia Scale meets the criteria of the psychometric equivalence with the original version. It is necessary to continue research using Polish version of the ISAS to provide a constatnt verification of reliability and accuracy of the research tool.

validation studies, anaesthesia, maxillofacial surgery, nursing care

POLSKA ADAPTACJA IOWA SATISFACTION WITH ANESHHESIA SCALE

Wprowadzenie. Praca prezentuje adaptację of the lowa Satisfaction with Anesthesia Scale do warunków polskich szpitali.

Materiał i metody. Proces adaptacji kulturowej lowa Satisfaction with Anesthesia Scale podzielono na trzy etapy. Pierwszy etap polegał na opracowaniu polskiej wersji ISAS. W etapie drugim zastosowano polską wersje ISAS w grupie pacjentów z rozpoznanym urazem szczękow- twarzowym, poddanych zabiegowi operacyjnemu. W etapie trzecim oceniono własności psychometryczne polskiej wersji ISAS.

Wyniki. Analizie poddano 195 poprawnie wypełnionych kwestionariuszy polskiej wersji ISAS zebrane od pacjentów oddziału klinicznego chirurgii Klinicznego Oddziału Chirurgii Szczękowo-Twarzowej operowanych w znieczuleniu ogólnym z powodu urazu szczękowo-twarzowego. Średni wynik oceny zadowolenia ze znieczulenia w badanej populacji wynosił 0,77 (skali od -3 do +3) M=2, $S D=2,41$. Współczynnik Alfa Cronbacha obliczony dla 11 pozycji testowych wynosi 0,598. Zwiększenie wartości współczynnika Alfa Cronbacha jest możliwe w przypadku wyeliminowania pozycji testowej pytania nr 1: Wymiotowałem lub czułem, że będę wymiotował ( maksymalnie - 0,601). Wszystkie pozycje skali miały istotny wpływ na jej wynik ogólny ( $p=0.0001$ ).

Wnioski. Polska wersja lowa Satisfaction with Anesthesia Scale spełnia wybrane kryteria równoważności psychometrycznej z wersją oryginalną.Konieczne są dalsze badania z użyciem polskiej wersji ISAS, aby zapewnić ciągłą weryfikację rzetelności i trafności narzędzia badawczego.

badania walidacyjne, anestezjologia, chirurgia szczękowo-twarzowa, opieka pielegniarska 


\section{INTRODUCTION}

Anaesthesia in maxillofacial surgery, as any other procedure concerning head and neck parts, is difficult. The surgical procedure is connected with numerous unpleasant experiences concerning physical and mental spheres. It applies to pre- and post-surgery stages. Majority of such surgeries are performed under general intratracheal anaesthesia with the use of inhalation anaesthetics, opioids and relaxants as well as controlled ventilation. The scope and time of the procedure make anaesthesiologists expand monitoring by direct blood pressure measurement, central venous pressure measurement, central temperature measurement and the urinary bladder catheterization $[1,2]$. Patient's satisfaction with anaesthesia plays a vital role in the subject literature $[3,4,5]$. The results of many studies have shown that rising satisfaction with anaesthesia reduces the number of ocurring adverse reactions $[6,7,8,9,10]$. Measuring the patient's satisfaction with anaesthesia is a complex process, however, the benefits of the analysis and its influence on the quality of care make this difficult task being challenged and constantly improved [11]. The available data show that there are several scales for measuring patient's satisfaction with anaesthesia $[4,5,12,13,14,15,16]$. After a detailed analysis it was determined that there are no available publications or questionnaires that are specific and compliant with psychometric criteria that could be used as tools for assessing patient's satisfaction with anaesthesia.

\section{AIM}

The aim of the study was an adaptation of the Iowa Satisfaction with Anesthesia Scale to Polish conditions as well as evaluation of psychometric features of its Polish version.

\section{METHODS}

The study was conducted in compliance with the Resolution of the Bioethical Committee of the Medical University in Poznan.

\section{Development of the Polish version of the lowa Satisfaction with Anesthesia Scale}

The process of the cultural adaptation of the Iowa Satisfaction with Anesthesia Scale was divided into three stages. Firstly, the Polish version of ISAS was prepared. Then, the Polish version was tested in a group of patients who suffered from a maxillofacial injury and were subject to surgical procedure. Finally, the psychometric features of the Polish version of ISAS were evaluated.

Iowa Satisfaction with Anesthesia Scale (ISAS) is a questionnaire assessing the level of patient's satisfaction with medical care after undergoing anaesthesia $[4,12]$. The scale consists of 11 questions (5 negative and 6 positive) which take maximum 4 to 5 minutes. In three of questions the patients are asked to assess the pain they experience. Despite being similarly formulated, the questions concern different aspects of pain expe- rience. In six of questions the patients are asked to report all the other feelings experienced during anaesthesia. In two questions the patients were asked to directly assess the anaesthesia experience. Each of the questions had the same 6-point answer scale according to the Stapel scale (strongly disagree, disagree, rather disagree, rather agree, agree, strongly agree) from -3 to +3 . The values were respectively reversed at the negatively formulated questions. The final score constituted an average value of all of the 11 questions [16]. While performing cultural adaptation of ISAS, the attention was paid to the guidelines proposed by Wild et al [17]. After receiving a positive reply from the scale's author, the process of translation of ISAS into Polish bagan. The original version was translated by two independent translators. A preliminary version of the scale was settled on the basis of both translations. The next step was a reversed translation from Polish into English, which was sent to Prof F. Dexter, the author of the original ISAS in order to receive his opinion and remarks concerning translation accuracy. Professor Dexter did not have any concerns. While preparing the Polish version of ISAS, there were used identical graphic form of the questionnaire with the same criteria of qualifying patients for the study and analogical course of the study procedure compliant with the instructions of the authors' original version. Particular stages of assessing patients' satisfaction, that is preparing the questionnaires and qualification criteria, as well as surveys distribution, collecting and checking, questions decoding and statistical analyses preparations were done according to the original guidelines.

\section{Using the Polish version of ISAS in a group of surgical patients diagnosed with maxillofacial injury}

The study group consisted of 198 patients hospitalised at the Clinical Ward for Maxillofacial Surgery who were operated under general anaesthesia from January 1st, 2009 to December $31^{\text {st }}, 2009$. When choosing place for conducting the study, the main aspect taken into consideration was the innovativeness of the facility. The Clinical Ward for Maxillofacial Surgery has a third-degree reference level and is the only facility of this kind in Podkarpackie Region in Poland. The participation in the study was voluntary. The patients were guaranteed the sense of confidentiality. Each of them was informed that despite the possibility of his/her identification by the register number or by the questionnaire number, the data obtained during the course of the study was to be used only for scientific purpose.

\section{The assessment of psychometric features of Polish version of ISAS}

While assessing the reliability of the Polish version of ISAS Cronbach- $a$ coefficient was used. The values $0.6-1.0$ were taken as confirming reliability of scale. Spearman's rank correlation coefficient was also implemented with the value of 0.4 and above as confirming significant dependency.

The theoretical accuracy of the Polish version was tested by analysing the internal structure of the scale. The way each question influences the general score was evaluated. 


\section{Statistical analysis}

Calculation of scores concerning patients' satisfaction with anaesthesia was done with the use of the Microsoft Office Excel 97-2003 calculation sheet as it was determined by the authors of the original procedure. The analysis was conducted using the Polish version of the statistical package STATISTICA 10 and SPSS. Basic descriptive measurements that were used in the statistical analysis included: mean, standard deviation, minimum and maximum values. The following rules were assumed: $p<0.05$ - statistically significant dependency (marked with ${ }^{\star}$ ); $\mathrm{p}<0.01$ - highly significant dependency (marked with ${ }^{\star *}$ ); $\mathrm{p}<0.001$ - dependency of very high statistical significance (marked with ${ }^{* * *}$ ). Cronbach- $\alpha$ coefficient and Spearman's rank correlation coefficient were used to the reliability of the Polish version of ISAS confirmation.

\section{RESULTS}

\section{The study group - characteristics}

The number of analysed questionnaires was eual to 198. Three of them were incomplete, therefore were rejected. The proper study group consisted of 195 questionnaires obtained from patients of the Clinical Ward for Maxillofacial Surgery operated under general anaesthesia due to maxillofacial trauma. There were 173 male (88.7\%) and 22 female (11.3\%) patients.

The injuries concerning the facial part of the cranium included: middle face fracture, comprising maxilla, nose, zygomatic bones and arches -93 cases (44.28\%), lower face fracture that is jawbone -79 people (37.61\%) and 15 cases $(7.14 \%)$ of upper face fracture and $4(1.90 \%)$ cases of both upper and middle face fractures (Table 1.) The biggest group of patients was qualified to II ASA (American Society of Anesthesiologists) group - 56.0\%, while $36.0 \%$ were qualified to I ASA and $6.0 \%$ and $2.0 \%$ to ASA III and ASA IV respectively (Tab. 1.)

- Tab. 1. Characteristic of patients' clinical condition.

\begin{tabular}{|c|c|}
\hline Variable & $\mathbf{N}(\%)$ \\
\hline Type of injury & $15(7.14 \%)$ \\
I & $93(44.28 \%)$ \\
III & $79(37.61 \%)$ \\
I-II & $4(1.90 \%)$ \\
II-III & $2(0.95 \%)$ \\
I-II-III & $1(0.47 \%)$ \\
\hline & Mean 88.48, SD-41.98 \\
Duration of anaesthesia & Min 20 min \\
& Max - $240 \mathrm{~min}$ \\
\hline ASA & \\
I & $69(36.0 \%)$ \\
II & $109(56.0 \%)$ \\
III & $13(6.0 \%)$ \\
IV & $4(2.0 \%)$ \\
V & $0(0 \%)$ \\
\hline
\end{tabular}

The average score of anaesthesia satisfaction in the study population was 0.77 (from -3 to +3 ), $\mathrm{M}=2, \mathrm{SD}=2.41$.

\section{Evaluation of chosen psychometric features of the Polish version of ISAS}

Scale's reliability was analysed on the basis of 195 questionnaires. Cronbach- $\alpha$ coefficient calculated for 11 test questions is 0.598 which indicates a moderate reliability of the scale (Tab. 2).

\section{Tab. 2. Cronbach-a coefficient for the Polish version of ISAS.}

\begin{tabular}{|c|c|}
\hline Cronbach- $a$ coefficient & Number of questions \\
\hline 0.598 & 11 \\
\hline
\end{tabular}

The value of Cronbach- $\alpha$ coefficient was analysed after eliminating individual questions. The increase in the value is possible in case of eliminating question 1: I vomited or felt nauseous (increase to 0.601). In case of the rest of questions, the value remained the same or decreased (Tab. 3).

Tab. 3. Cronbach-a coefficient for the Polish versions of ISAS after eliminating individual questions.

\begin{tabular}{|l|c|}
\hline \multicolumn{1}{|c|}{ Question } & $\begin{array}{c}\text { Cronbach-a after } \\
\text { eliminating } \\
\text { the question }\end{array}$ \\
\hline Question 1. I vomited or felt nauseous & .601 \\
\hline $\begin{array}{l}\text { Question 2. I would like to undergo } \\
\text { the same anaesthesia again }\end{array}$ & .598 \\
\hline Question 3. I felt itchy & .554 \\
\hline Question 4. I felt relaxed & .553 \\
\hline Question 5. I felt pain & .584 \\
\hline Question 6. I felt safe & .590 \\
\hline Question 7. I was too cold or too hot & .543 \\
\hline Question 8. I was satisfied with anesthesiological care & .599 \\
\hline Question 9. I experienced pain during the surgery & .531 \\
\hline Question 10. I felt good & .593 \\
\hline Question 11. I was sore & .566 \\
\hline
\end{tabular}

Theoretical accuracy of satisfaction scale was studied by analysing its internal structure. The way individual questions influence the general score was evaluated. All of the questions had a significant impact on the final score (Tab. 4).

Tab. 4. Spearman's rank correlation coefficient for questions and for the final score of the Polish version of ISAS.

\begin{tabular}{|l|c|c|}
\hline \multicolumn{1}{|c|}{ Question } & $\begin{array}{c}\text { Spearman's rank } \\
\text { correlation coefficient }\end{array}$ & $\begin{array}{c}\text { Bilateral } \\
\text { significance }\end{array}$ \\
\hline Question 1. I vomited or felt nauseous & $0.560^{*}$ & 0.0001 \\
\hline $\begin{array}{l}\text { Question 2. I would like to undergo } \\
\text { the same anaesthesia again }\end{array}$ & $0.597^{*}$ & 0.0001 \\
\hline Question 3. I felt itchy & $0.744^{*}$ & 0.0001 \\
\hline Question 4. I felt relaxed & $0.523^{*}$ & 0.0001 \\
\hline Question 5. I felt pain & $0.454^{*}$ & 0.0001 \\
\hline Question 6. I felt safe & $0.622^{*}$ & 0.0001 \\
\hline Question 7. I was too cold or too hot & $0.548^{*}$ & 0.0001 \\
\hline $\begin{array}{l}\text { Question 8. I was satisfied with } \\
\text { anesthesiological care }\end{array}$ & $0.487^{*}$ & 0.0001 \\
\hline $\begin{array}{l}\text { Question 9. I experienced pain during } \\
\text { the surgery }\end{array}$ & $0.492^{*}$ & 0.0001 \\
\hline Question 10. I felt good & $0.542^{*}$ & 0.0001 \\
\hline Question 11. I was sore & $0.697^{*}$ & 0.0001 \\
\hline
\end{tabular}

*marks the significance level $p<0.01$ 


\section{DISCUSION}

The aim of the study was to adapt the Iowa Satisfaction with Anesthesia Scale to Polish conditions. The Polish version of the questionnaire was used in a study among patients who were operated under general anaesthesia after being diagnosed with a maxillofacial injury.

The results of the study indicate a moderately positive level of satisfaction with anaesthesia as based on the Polish version of ISAS. The average score for the entire scale was $0.77 \mathrm{M}=2, \mathrm{SD}=2.41$ (range from -3 to +3 ). None of the 11 questions gained a negative score. All of the scale's questions have a significant impact on the final score. A very similar average result measuring satisfaction with anaesthesia was obtained in a study conducted in Spain and was equal to 0.80 [18]. Higher results of satisfaction with anaesthesia -0.87 were obtained in a Canadian study [19].

The reliability of the Polish version of ISAS obtained $0.598(n=195)$ for Cronbach- $\alpha$ coefficient calculated for 11 questions, what indicates its moderate equivalence. This is lower than in the study by Dexter et al. [4] -0.80 $(n=80)$, which most likely results from the fact that the group of patients suffering from maxillofacial injury was operated under general anaesthesia. The values of own scores were close to those presented by Fung et al. [19], the Cronbach- $\alpha$ coefficient was 0.68 for entire population after cataract surgery.
There was a slight increase in the Cronbach- $a$ coefficient after eliminating Question 1. I vomited or felt nauseous (to a maximum of 0.601 ). In case of the remaining questions the values of the coefficient remained relatively the same. Similar results were presented by Garcia et al [20] in patients after ophthalmic surgeries.

Own results include patients with maxillofacial injury operated under general anaesthesia and although we have confirmed the psychometric features, we believe that there should be further studies implementing the Polish version of ISAS in the group of patients undergoing surgical procedures under general anaesthesia.

\section{CONCLUSIONS}

In conclusion, the Polish version of the ISAS meets the chosen criteria of functional and psychometric equivalence with accordance to its original version. It is necessary to continue further studies using the Polish version of the ISAS to ensure continuous verification of reliability and validity of the research tool.

\section{ACKNOWLEDGMENTS}

The team of authors would like to thank the authors of ISAS from the Iowa University for allowing its adaptation to Polish conditions.

\section{Polska adaptacja lowa Satisfaction with Anesthesia Scale}

\section{WPROWADZENIE}

Znieczulenia w chirurgii szczękowo-twarzowej oraz do operacji w obrębie głowy i szyi należą do trudnych procedur. Zabieg operacyjny wiąże się z wieloma nieprzyjemnymi doznaniami sfery fizycznej i psychicznej człowieka. Dotyczy to zarówno okresu przed, jak i po operacji. Do większości zabiegów wykonuje się znieczulenie ogólne dotchawicze z zastosowaniem środków wziewnych, opioidów i środków zwiotczających oraz wentylacji kontrolowanej. Rozległość, czas trwania operacji zmusza anestezjologa do rozszerzenia monitorowania o bezpośredni, krwawy pomiar ciśnienia tętniczego, pomiar ośrodkowego ciśnieniażylnego, centralny pomiar temperatury oraz cewnikowanie pęcherzan moczowego $[1,2]$. W literaturze przedmiotu bardzo dużą rolę przypisuje się satysfakcji pacjenta ze znieczulenia $[3,4,5]$. Wyniki wielu badań wykazały, że wzrost zadowolenia ze znieczulenia powoduje ograniczenie ilości działań niepożądanych $[6,7,8,9,10]$.

Pomiar satysfakcji pacjenta $\mathrm{z}$ opieki anestezjologicznej jest procesem złożonym, jednakże korzyści płynące $\mathrm{z}$ analizy poziomu satysfakcji i jej wpływ na zapewnianie jakości opieki, powodują, że to trudne zadanie jest podejmowane i stale doskonalone [11]. Z dostępnych danych wynika, że jest kilka skal służących do pomiaru satysfakcji pacjenta ze znieczulenia $[4,5,12,13,14,15,16]$. W Polsce na podstawie analizy dostępnej literatury stwierdzono, że brak jest specyficznych i spełaniajacych kryteria psychmetryczne kwestionariuszy służących do oceny satysfakcji pacjenta ze znieczulenia.

\section{CEL PRACY}

Celem badania był adaptacja narzędzia: the Iowa Satisfaction with Anesthesia Scale (ISAS) do warunków polskich.

\section{MATERIAŁ I METODY}

Badania przeprowadzono zgodnie z Uchwałą Komisji Bioetycznej Uniwersytetu Medycznego w Poznaniu.

\section{Opracowanie polskiej wersji lowa Satisfaction with Anesthesia Scale}

Proces adaptacji kulturowej narzędzia: the Iowa Satisfaction with Anesthesia Scale podzielono na trzy etapy Pierwszy etap polegał na opracowaniu polskiej wersji ISAS. W etapie drugim zastosowano polską wersje ISAS $\mathrm{w}$ grupie pacjentów $\mathrm{z}$ rozpoznanym urazem szczękow- twarzowym, poddanych zabiegowi operacyjnemu. W etapie trzecim oceniono własności psychometryczne polskiej wersji ISAS. The Iowa Satisfaction with Anesthesia Scale (ISAS) to kwestionariusz mierzący poziom zadowolenia pacjenta $\mathrm{z}$ opieki medycznej po przeprowadzonym znieczuleniu [4,12]. Skala składa się z 11 pytań 
(5 negatywnych i 6 pozytywnych), na które ‘odpowiedzi zajmują maksymalnie 4-5 min. W trzech pozycjach skali pacjenci są pytani o ocenę odczuwanego bólu. Pomimo podobnych sformułowań pytania dotyczą odmiennych aspektów doświadczeń bólowych pacjentów. W sześciu pozycjach pytania dotyczyły zgłaszania wszelkich innych odczuć, które miały miejsce podczas znieczulenia. $\mathrm{W}$ dwóch pozycjach pacjenci byli proszeni o dokonanie bezpośredniej oceny doświadczeń ze znieczulenia. Każda pozycja zawiera ten sam sześciopunktowy format odpowiedzi wg skali Stapela (zdecydowanie się nie zgadzam, nie zgadzam się, raczej się nie zgadzam, raczej się zgadzam, zgadzam się, zdecydowanie się zgadzam) od -3 do +3. Wartości zostały odpowiednio odwrócone przy negatywnie sformowanych pozycjach. Ostateczny wynik kwestionariusza stanowi średnią wartość wszystkich 11 pozycji [16]. W procesie adaptacji kulturowej ISAS zwrócono uwagę na zasady zaproponowane przez Wilda i wsp. [17]. Po uzyskaniu pozytywnej odpowiedzi autora skali rozpoczęto procedurę tłumaczenia oryginalnej wersji skali ISAS na jezyk polski. Wersja oryginalna tłumaczona była przez dwóch niezależnych tłumaczy. Ustalono na podstawie tłumaczeń wstępną wersję skali. Nastepnie przeprowadzono zwrotne tłumaczenie $\mathrm{z}$ języka polskiego na język angielski przez niezależnego tłumacza, która nastepnie została przesłana do autora oryginalnej ISAS Prof. F. Dextera w celu pozyskania opinii i uwag dotyczących wierności tłumaczenia. Profesor Dexter nie miał zastrzeżeń co do procedury przygotowania i tłumaczenia polskiej wersji ISAS. Przygotowując polska wersję ISAS, zastosowano identyczną formę graficzną kwestionariusza skali, przyjęto takie same kryteria doboru próby badanej, zastosowano analogiczny przebieg procedury badawczej zgodny z instrukcją opracowaną przez autorów wersji oryginalnej. Zachowano te same wytyczne dotyczące postepowania na poszczególnych etapach prowadzenia badania satysfakcji pacjentów, przygotowania kwestionariuszy badawczych, kryteriów uczestnictwa, dystrybucji ankiet, odbioru ankiet, sprawdzenia, przekodowania pytań i analiz statystycznych.

\section{Zastosowanie polskiej wersji ISAS w grupie pacjentów operowanych z rozpoznanym urazem szczękow-twarzowym}

Grupę badaną stanowiło 198 pacjentów przyjętych do Klinicznego Oddziału Chirurgii Szczękowo-Twarzowej operowanych w znieczuleniu ogólnym z powodu urazu szczękowo-twarzowego. Dane o pacjentach gromadzono w okresie od 1 stycznia 2009 r. do 31 grudnia 2009 r. Podczas wyboru miejsca badań kierowano się tym, aby były innowacyjne. Oddział Kliniczny Chirurgii Szczękowo -Twarzowej posiada III stopień referencyjności i jest jedynym takim na terenie województwa podkarpackiego w Polsce. Udział w badaniu był dobrowolny, pacjent musiał mieć zagwarantowane poczucie poufności przeprowadzonych badań. Musiał wiedzieć, że chociaż jego identyfikacja będzie możliwa na podstawie numeru w rejestrze i numeru wypełnionego kwestionariusza ankiety, to uzyskane dane wykorzystane będą jedynie przez prowadzących badanie do celów naukowych.

\section{Ocena własności psychometrycznych polskiej wersji ISAS}

W ocenie rzetelności polskiej wersji ISAS zastosowano współczynnik Alfa Cronbacha, gdzie wartość 0,6-1,0 przyjęto jako wartość potwierdzającą rzetelność skali. Współczynnik korelacji rang Spearmana - wartość 0,4 i powyżej przyjęto jako potwierdzającą istotną zależność. Trafność teoretyczną polskiej wersji ISAS badano za pomocą analizy struktury wewnętrznej skali. Oceniano, w jaki sposób poszczególne pytania testu wpływają na wynik ogólny skali.

\section{Analiza statystyczna}

Obliczenia wyników dotyczących satysfakcji pacjentów ze znieczulenia przeprowadzono za pomocą arkusza kalkulacyjnego Microsoft Office Excel 97-2003 zgodnie z procedurą określoną przez autorów wersji oryginalnej skali. Analizy przeprowadzono wykorzystując pakiet statystyczny STATISTICA 10 wersja polska oraz program SPSS.

W analizie statystycznej posłużono się podstawowymi miarami opisowymi dostosowanymi do zmiennych, tj. średnia, odchylenie standardowe, wartości minimalne i maksymalne. Przyjęto następujące reguły: $\mathrm{p}<0,05$ mówimy o statystycznie istotnej zależności (oznaczono ten fakt za pomocą $\left.{ }^{*}\right) ; \mathrm{p}<0,01$ to wysoce istotna zależność (oznaczono ten fakt za pomocą ${ }^{*}$ ); $\mathrm{p}<0,001$ to bardzo wysoko istotna statystycznie zależność (oznaczono ten fakt za pomocą $\left.{ }^{\star * \star}\right)$. W ocenie rzetelności polskiej wersji ISAS wykorzystano współczynnik Alfa Cronbacha i współczynnik korelacji rang Spearmana dla potwierdzenia istotnej zależności.

\section{WYNIKI}

\section{Charakterystyka badanej grupy}

Analizie poddano 198 kwestionariuszy polskiej wersji ISAS w tym trzy jako niekompletne zostały odrzucone. Ostateczna grupa stanowiła kwestionariusze zebrane od 195 pacjentów oddziału klinicznego chirurgii Klinicznego Oddziału Chirurgii Szczękowo-Twarzowej operowanych w znieczuleniu ogólnym z powodu urazu szczękowo-twarzowego. W grupie tej 173 osoby stanowili mężczyzni $(88,7 \%)$ i 22 kobiety (11,3\%). Obrażeniem w obrębie części twarzowej czaszki, było złamanie środkowego piętra twarzy, które obejmuje szczęki, nos od podstawy oraz kości i łuki jarzmowe w 93 przypadkach (44,28\%), złamanie dolnego piętra twarzy, czyli żuchwy 79 osób $(37,61 \%)$ u $15(7,14 \%)$ chorych urazy górnego piętra twarzy oraz w 4 (1,90\%) przypadkach doszło do urazu górnego i środkowego piętra twarzy (Tab.1). Największa grupę pacjentów zakwalifikowano do II gr wg ASA - 56,0\%, następnie $36,0 \%$ ankietowanych do I grupy, zaś $6,0 \%$ kwalifikowało się do grupy III i 2,0\% pacjentów do grupy IV (Tab.1). Średni wynik oceny zadowolenia ze znieczulenia w badanej populacji wynosił 0,77 (skali od -3 do +3 ) $M=2$, $\mathrm{SD}=2,41$. 
Tab. 1. Charakterystyka stanu klinicznego pacjentów.

\begin{tabular}{|c|c|}
\hline Zmienna & $\mathbf{N}(\%)$ \\
\hline Typ urazu & $15(7,14 \%)$ \\
I & $93(44,28 \%)$ \\
II & $79(37,61 \%)$ \\
III & $4(1,90 \%)$ \\
I-II & $2(0,95 \%)$ \\
II-III & $1(0,47 \%)$ \\
I-II-III & Średnia 88,48, SD-41,98 \\
\hline & Min 20 min \\
Czas trwania znieczulenia & \\
& $69(36,0 \%)$ \\
ASA & $109(56,0 \%)$ \\
I & $13(6,0 \%)$ \\
II & $4(2,0 \%)$ \\
III & $0(0 \%)$ \\
\hline
\end{tabular}

\section{Ocena wybranych właściwości psychometrycznych polskiej wersji ISAS}

Rzetelność skali analizowano na podstawie $195 \mathrm{kwe}$ stionariuszy. Współczynnik Alfa Cronbacha obliczony dla 11 pozycji testowych wynosi 0,598 co wskazuje na umiarkowaną rzetelność skali (Tab. 2).

Tab. 2. Współczynnik Alfa Cronbacha dla Polskiej wersji ISAS.

\begin{tabular}{|c|c|}
\hline Współczynnik Alfa Cronbacha & Liczba pozycji \\
\hline 0,598 & 11 \\
\hline
\end{tabular}

Analizowano wartość współczynnika Alfa Cronbacha po usunięciu poszczególnych pytań skali. Zwiększenie wartości współczynnika Alfa Cronbacha jest możliwe w przypadku wyeliminowania pozycji testowej: pytanie 1 . Wymiotowałem lub czułem, że będę wymiotował (wzrost wartości współczynnika Alfa Cronbacha do wartości najwyższej 0,601). W przypadku pozostałych pozycji wartość współczynnika utrzyma się na tym samym poziomie lub ulegały obniżeniu (Tab. 3).

Tab. 3. Współczynnik Alfa Cronbacha dla Polskiej wersji ISAS po usunięciu poszczególnych pozycji testowych.

\begin{tabular}{|l|c|}
\hline \multicolumn{1}{|c|}{ Pozycja testowa } & $\begin{array}{c}\text { Współczynnik } \\
\text { Alfa Cronbacha po } \\
\text { usunięciu pozycji }\end{array}$ \\
\hline Pytanie 1. Wymiotowałem lub czułem, że będę wymiotował &, 601 \\
\hline Pytanie 2. Chciałabym mieć takie znieczulenie ponownie &, 598 \\
\hline Pytanie 3.Miałem uczucie swędzenia &, 554 \\
\hline Pytanie 4.Czułem się zrelaksowany &, 553 \\
\hline Pytanie 5.Czułem ból &, 584 \\
\hline Pytanie 6. Czułem się bezpieczny &, 590 \\
\hline Pytanie 7. Było mi zbyt zimno lub gorąco &, 543 \\
\hline $\begin{array}{l}\text { Pytanie 8. Byłem zadowolony z mojej opieki } \\
\text { anestezjologicznej }\end{array}$ &, 599 \\
\hline Pytanie 9. Czułem ból w trakcie zabiegu &, 531 \\
\hline Pytanie 10.Czułem się dobrze &, 593 \\
\hline Pytanie 11. Byłem obolały &, 566 \\
\hline
\end{tabular}

Trafność teoretyczną skali zadowolenia ze znieczulenia badano za pomocą analizy struktury wewnętrznej skali. Oceniano, w jaki sposób poszczególne pytania testu wpływają na wynik ogólny skali. Wszystkie pozycje skali miały istotny wpływ na jej wynik ogólny (Tab.4).

Tab. 4. Współczynnik korelacji rang Spearmana dla pozycji testowych i wyniku ogólnego Polskiej wersji ISAS.

\begin{tabular}{|l|c|c|}
\hline \multicolumn{1}{|c|}{ Pozycja testowa } & $\begin{array}{c}\text { Współczynnik } \\
\text { korelacji Spearmana }\end{array}$ & $\begin{array}{c}\text { Istotność } \\
\text { dwustronna }\end{array}$ \\
\hline $\begin{array}{l}\text { Pytanie 1. Wymiotowałem lub czułem, } \\
\text { że będę wymiotował }\end{array}$ & $0,560^{*}$ & 0,0001 \\
\hline $\begin{array}{l}\text { Pytanie 2. Chciałabym mieć takie } \\
\text { znieczulenie ponownie }\end{array}$ & $0,597^{*}$ & 0,0001 \\
\hline Pytanie 3.Miałem uczucie swędzenia & $0,744^{*}$ & 0,0001 \\
\hline Pytanie 4.Czułem się zrelaksowany & $0,523^{*}$ & 0,0001 \\
\hline Pytanie 5.Czułem ból & $0,454^{*}$ & 0,0001 \\
\hline Pytanie 6. Czułem się bezpieczny & $0,622^{*}$ & 0,0001 \\
\hline Pytanie 7. Było mi zbyt zimno lub gorąco & $0,548^{*}$ & 0,0001 \\
\hline $\begin{array}{l}\text { Pytanie 8. Byłem zadowolony z mojej } \\
\text { opieki anestezjologicznej }\end{array}$ & $0,487^{*}$ & 0,0001 \\
\hline Pytanie 9. Czułem ból w trakcie zabiegu & $0,492^{*}$ & 0,0001 \\
\hline Pytanie 10.Czułem się dobrze & $0,542^{*}$ & 0,0001 \\
\hline Pytanie 11. Byłem obolały & $0,697^{*}$ & 0,0001 \\
\hline
\end{tabular}

*oznacza poziom istotności $p<0,01$

\section{DYSKUSJA}

Celem badania była adaptacja narzędzia the Iowa Satisfaction with Anesthesia Scale do warunków polskich . Przyjętą polską wersję kwestionariusza the Iowa Satisfaction with Anesthesia Scale zastosowano do badania w grupie pacjentów operowanych w znieczuleniu ogólnym $z$ rozpoznanym urazem szczękowo-twarzowym.

Wyniki badań własnych wykazują na umiarkowanie pozytywny poziom zadowolenia pacjentów ze znieczulenia w oparciu o Polską wersję ISAS. Średnia wyniku dla całej skali wynosiła $0,77 \mathrm{M}=2, \mathrm{SD}=2.41$ (zakres skali -3 do +3$)$. Żadne z 11 pytań nie uzyskało wyniku negatywnego. Wszystkie pozycje skali mają istotny wpływ na jej wynik ogólny. Bardzo zbliżony średni ogólny wynik poziomu satysfakcji ze znieczulenia uzyskano w toku badań wykorzystujących skalę ISAS, przeprowadzonych w Hiszpanii,wynosił on 0,80 [18]. Wyższe wyniki zadowolenia ze znieczulenia 0,87 uzyskano w badaniach przeprowadzonych w Kanadzie [19]. Rzetelność polskiej wersji skali ISAS na podstawie współczynnika Alfa Cronbacha obliczona dla 11 pozycji testowych wynosiła 0,598 $(\mathrm{n}=195)$ co wskazuje na umiarkowaną rzetelność skali, nizszą niż $0,80(n=80)$ w wynikach podawanych przez Dexter i wsp.[ 4], prawdopodobnie dlatego że grupa chorych z urazem szczękowo-twarzowym była operowna w znieczuleniu ogólnym. Wartości wyników własnych były zblizone do prezentowanych przez by Fung i wsp. [19], współczynnika Alfa Cronbacha 0.68 dla całej populacji po operacji zaćmy. Zauważono niewielkie zwiększenie wartości współczynnika Alfa Cronbacha w przypadku wyeliminowania pozycji testowej pytanie 1 . Wymiotowałem lub czułem, że będę wymiotował. W przypadku 
pozostałych pozycji wartość współczynnika utrzymywała się na zbliżonym poziomie. Podobne wyniki prezentowane były przez García i wsp. [20] u pacjentów po operacjach okulistycznych. Nasze wyniki dotyczą pacjentów $\mathrm{z}$ urazem twarzo-czaszki operowanych w znieczuleniu ogólnym i choć uzyskaliśmy potwierdzenie właściwości psychometryczne to uważamy, że należy podejmować dalsze badania $z$ zastosowaniem polskiej wersji ISAS w grupie pacjentów poddawanych zabiegom chirurgicznym w znieczuleniach innych niż ogólne.

\section{WNIOSKI}

Polska wersja the Iowa Satisfaction with Anesthesia Scale spełnia wybrane kryteria równoważności psychometrycznej z wersją oryginalną. Konieczne są dalsze badania z użyciem polskiej wersji ISAS, aby zapewnić ciągłą weryfikację rzetelności i trafności narzędzia badawczego.

\section{PODZIĘKOWANIA}

Zespół autorów dziękuję autorom skali ISAS z Uniwersytetu Iowa za zgodę na walidację do warunków Polskich.

\section{PIŚMIENNICTWO/REFERENCES}

1. Wanyura H. Urazy szkieletu czaszkotwarzowego. Kryst L. (red.). Chirurgia Szczękowo-twarzowa. Warszawa: PZWL; 2007.

2. Wołowicka L, Dyk D. Anestezjologia i intensywna terapia. Klinika i pielęgniarstwo. Warszawa: PZWL, 2008.

3. Paleczny J, Łoniewska-Paleczny E, Pysz M, Hura G. Porównanie zastosowania piersiowej blokady przykręgowej i znieczulenia ogólnego w chirurgii gruczołu piersiowego. Anestezjologia Intensywna Terapia. 2005; 37: 12-16.

4. Dexter F, Aker J, Wright W. Development of a Measure of Patient Satisfaction with Monitored Anesthesia Satisfaction with Anesthesia Scale. Anesthesia Analgesia. 1997; 87(4): 865-873.

5. Fung D, Marsha M. What Determines Patient Satisfaction with Cataract Care Under Topical Local Anesthesia and Monitored sedation In a Community Hospital Setting. Anesthesia Analgesia. 2005; 100: 1644-1650.
6. Cohen M, Duncan P, Pope W, et al. The Canadian four-centre study of anesthetic outcomes. II. Can outcomes be used to assess the quality of anesthesia care? Canadian Journal of Anesthesia. 1992; 5: 430-439.

7. Eagle CJ, Davies JM. Current models of "quality": an introduction for anesthetists. Canadian Journal of Anesthesia. 1993; 9: 851-862.

8. Pagenkopf D, Davies JM, Bahan M, et al. A complementary approach to outcome analysis in the parturient. International Journal of Health Care Quality Assurance. 1991;4:241-245.

9. Duncan P. Quality: a job well done!. Canadian Journal of Anesthesia. 1993; 9: 813815.

10. Orkin $F$, Cohen $M$, Duncan P. The quest for meaningful outcomes. Anesthesiology. 1993; 3: 417-422.

11. Meakin R, Weinman J. The Medical interview Satisfaction scale` (MISS-21) adapter for British general Practice. Family Practice. 2002; 19: 257-263.

12. Fleisher L.A, Mark L. Disseminating information using an anesthesiology Consultant report: impast on patient perceptions of quality of care. Journal of Clinical Anesthesia. 1999; 11(5): 380-385.

13. Pascal A. Development and Validation of a Perioperative Satisfaction Questionnaire. Anesthesiology. 2005; 102: 1116-1123.

14. Capuzzo M, Landi F, Bassani A, et al. Emotional and interpersonal factors are most important for patient satisfaction with anaesthesia. Acta Anaesthesiologica Scandinavica. 2005; 49: 735-742.

15. Schiff JH, Fornaschon AS. The Heidelberg Peri-anaesthetic Questionnairedevelopment of a New refined psychometric questionnaire. Anesthesia. 2008; 63: 1096-1104.

16. Dexter F, Candiotti K. Multicenter Assessment of the lowa Satisfaction with Anesthesia Scale, an Instrument that Measures Patient Satisfaction with Monitored Anesthesia Care. Anesthesia Analgesia. 2011; 113(2): 364-368.

17. Wild D, Grave A, Marti M, et al. Principles of good practice for the translation and cultural adaptation process for patient-reported outcomes (PRO) measures: Report of the ISPOR Task Force for Translation and Cultural Adaptation. Value in Health. 2005; 8: 94-104.

18. Benatar-Haserfaty J, Monleon de la Calle, Sanz- Lopez A, Muriel Garcia A. Outpatient external dacryocystorhinostomy under regional anesthesia and sedation. Revista Española de Anestesiología y Reanimación. 2007; 54(1): 23-28.

19. Fung D, Cohen M, Stewart S, Davies A. Can the lowa Satisfaction with Anesthesia Scale be used to measure patient satisfaction with cataract care under topical local anesthesia and monitored at a community hospital? Anesthesia Analgesia. 2005; 100(6): 1637-1643.

20. Jiménez GarcíaF, Del Real Capera A. Validation to Spanish of the lowa Satisfaction with Anesthesia Scale (ISAS) for monitored anesthesia care in ophthalmic surgery. Rev Col Anesth. 2014; 42: 272-280.

Praca przyjęta do druku/Manuscript received: 12.10.2016

Praca zaakceptowana do druku/Manuscript accepted: 15.12.2016

Tłumaczenie/Translation: Anna Nowak 